InVisible Culture • Issue 31: Black Studies Now and the CounterCurrents of Hazel Carby

\title{
Introduction / Issue 31: \\ Black Studies Now and the \\ Countercurrents of Hazel \\ Carby
}

Joel Burges ${ }^{1}$, Alisa V. Prince ${ }^{1}$, Jeffrey Allen Tucker ${ }^{1}$

${ }^{1}$ University of Rochester

Published on: Nov 15, 2020

DOI: $10.47761 / 2020.31 .00$

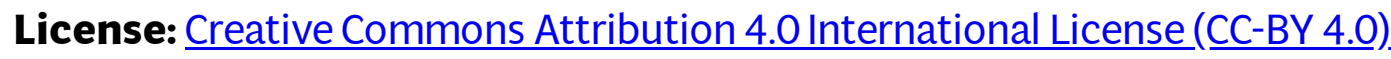




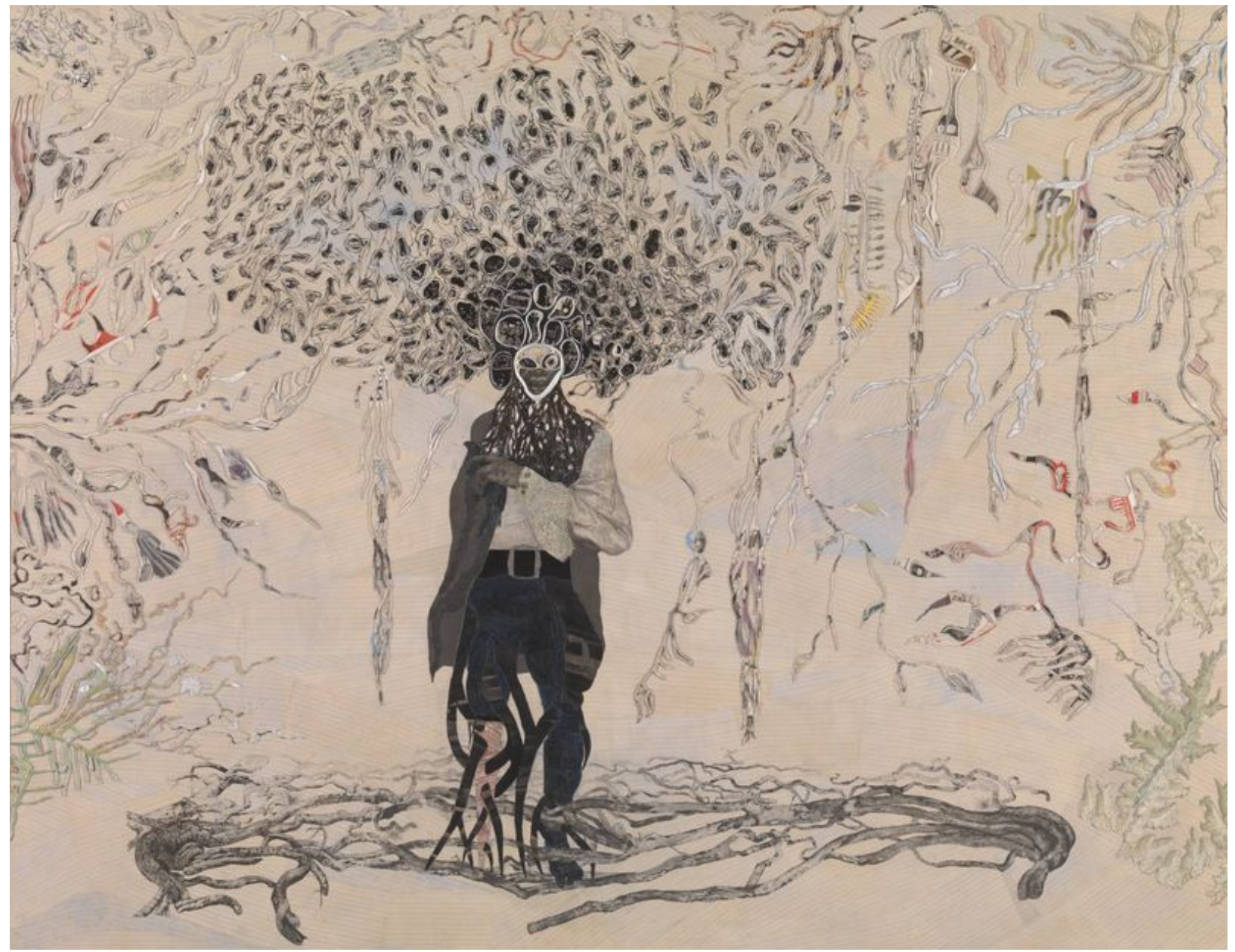

Featured Image: Ellen Gallagher, Bird in Hand, 2006. (C) Ellen Gallagher. Image (C) Tate.

She was dismayed when she realized that what she wanted to imagine, what she was struggling to bring into being, now seemed beyond her reach. Was it improbable or impossible? What could she dream in a present of imminent environmental catastrophe? How could she sculpt the contours of a future when the future, any future, had been foreclosed? - Hazel V. Carby, "Black Futurities: Shape-Shifting beyond the Limits of the Human" 1

In winter 2019, when Hazel V. Carby came to the University of Rochester (UR) as the Distinguished Visiting_Humanist, no one knew global pandemic and large-scale antiracist protests awaited us one year later in the spring, summer, and now fall of 2020. 2 We did not anticipate the rise of an anti-immigrant visa crisis in higher education as we began to write this introductory essay, or the revelation of the death of Daniel Prude as we were finalizing this issue of InVisible Culture (IVC). The unnecessary death of Prude 
-a Black man experiencing a mental health crisis in March 2020 while visiting Rochester, NY from Chicago, IL-has been declared a homicide resulting from asphyxiation while the police restrained him with a hood over his head in the midst of that crisis, as recently released video shows. $\underline{3}$ In retrospect, that all of this upheaval was coming was perhaps signaled by the harsh weather in winter 2019. It was bitterly cold on the days Carby visited, so cold that her plane was delayed on her way to Rochester. This delay was due to the frigid winds that blow through New York winters, exacerbated by a polar vortex that forced Carby to stay overnight at JFK as she tried to get here. Once she was able to make it to freezing Rochester, Carby did what she has done since she passed through the crucible of 1968: speak in a voice resonant with and resistant to power on a range of topics urgent to the world at present. $\underline{4}$

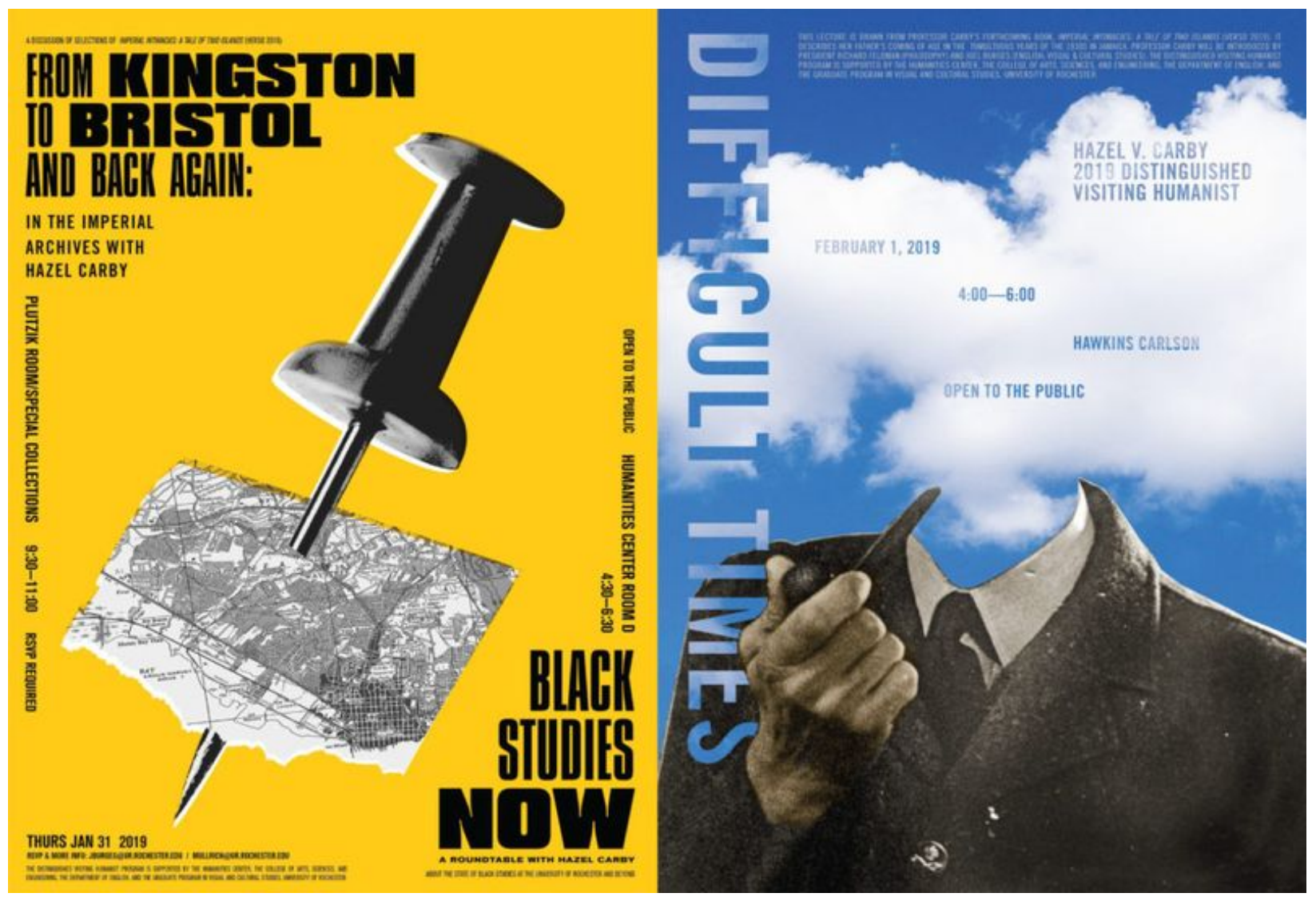

Figure 1: Promotional posters created for the events of Hazel Carby's visit to the University of Rochester in 2019, designed by Adam Maida.

In "From Kingston to Bristol and Back Again: In the Imperial Archives with Hazel Carby," Pablo Miguel Sierra Silva (Associate Professor, Department of History) and Miranda Mims (Director of Rare Books and Special Collections) discussed the violence of the archives of empire with Carby and a small audience, which had read draft 
sections of her now published Imperial Intimacies: A Tale of Two Islands. $\underline{5}$ A larger audience came together for the roundtable "Black Studies Now." There, Carby responded to visions of what Black Studies could be at the University of Rochester and beyond from faculty in Modern Languages and Cultures (Cilas Kemedjio and Will Bridges), English (Jeffrey Allen Tucker and Matthew Omelsky), Music (Darren Mueller and Cory Hunter), and Anthropology (Kathryn A. Mariner). She urged us all not only to honor the history of the field and to assert its vitality and value at present, but also to consider the future of Black Studies. She reminded us to imagine that future in relation to the specific conditions and histories of UR, whether they be the carceral landscape in which we are situated, the segregated city for which we are the biggest employer, the Indigenous lands on which our school sits, the lack of universal healthcare for our graduate students, or the devastatingly few faculty of color that UR employs. Her public lecture, “Difficult Times," was drawn from her then forthcoming Imperial Intimacies; it described her father's coming of age in the tumultuous years of the 1930s in Jamaica. At least 150 students, staff, administrators, and community members assembled in that Rochester winter to hear a lecture charged by a history both personal and political for Carby herself. 


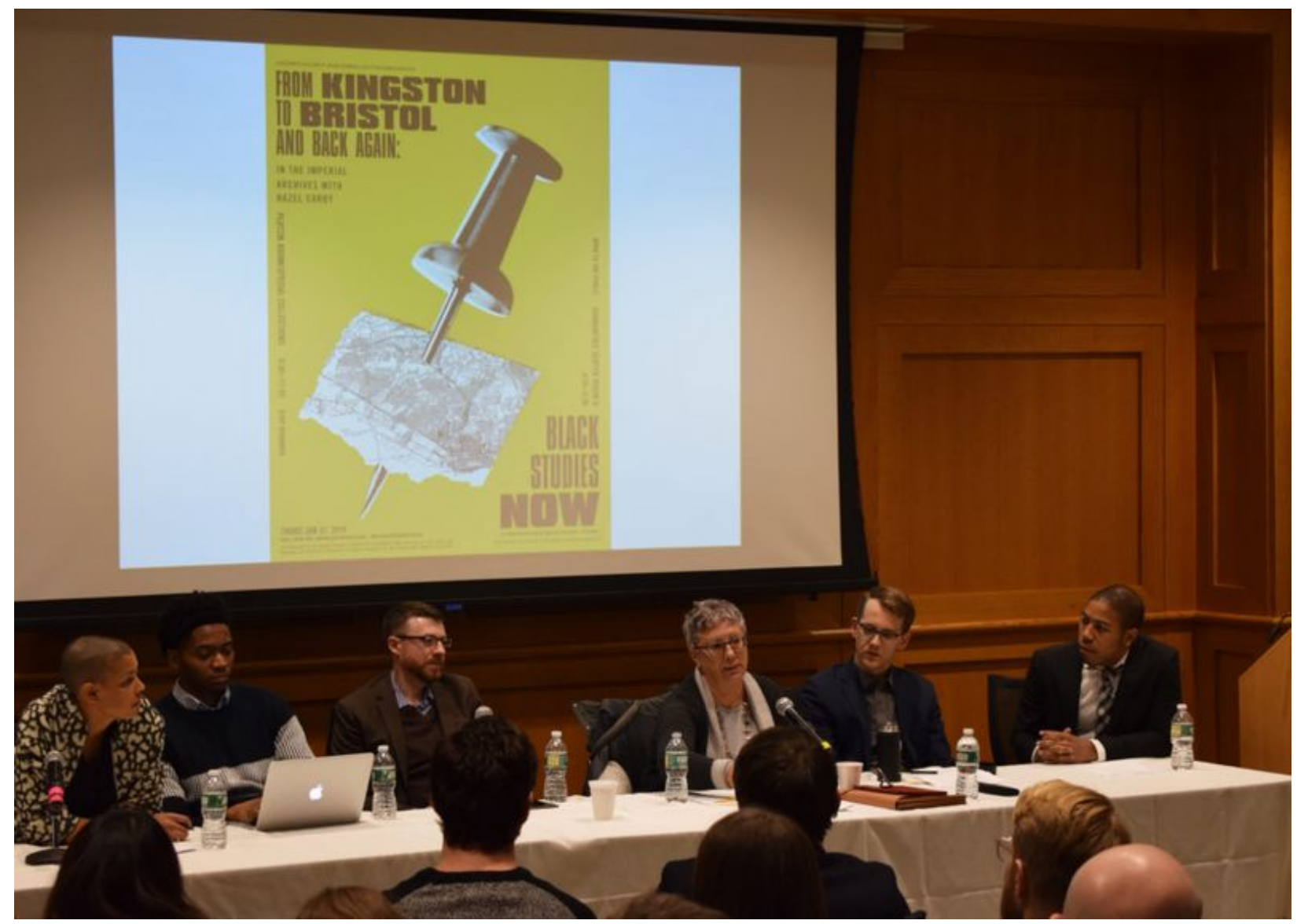

Figure 2: The Black Studies Now roundtable at the University of Rochester's Humanities Center. Participants, from left to right: Kathryn Mariner, Cory Hunter, Darren Mueller, Hazel Carby, Matthew Omelsky, and Will Bridges. Not shown: Cilas Kemedjio and Jeffrey Tucker. Photo by Julia Tulke.

More than a year later, some of those who assembled for "Difficult Times" found ourselves standing outside in the sun, mobilized against police brutality in the midst of a pandemic, rhythmically chanting "WE. CAN. NOT. BREATHE” with thousands of others worldwide, including in Rochester, NY (clip 1). This chant collectivized in the voices of the still living what Black men such as George Floyd and Eric Garner said as they died in police chokeholds without reason. It turned their plea into a demand for a world where police can no longer asphyxiate Black men such as Daniel Prude as a matter of routine practice without consequences, and where safety and justice mean something more universally restorative than racially determined punishment and policing. As we write-and we very much feel the pressure of the historical moment in which we are writing - this demand continues to resound at protests beyond Rochester in places such as Kenosha, WI, Louisville, KY, Portland, OR, and Minneapolis, MN. 


\section{Visit the web version of this article to view interactive content.}

\section{Clip 1: Chanting at a protest in downtown Rochester, NY on June 6, 2020. Video by Joel Burges.}

Since Carby's visit to UR in 2019, the currents of our historical moment have shifted. They have gained mass and momentum beyond the seminar rooms and lecture halls in which, always taking Carby's indelible thinking and writing as points of departure, we shared ideas last winter. Now we cannot enter those spaces so easily. Now we find ourselves at home social distancing. Now we are in the streets protesting. Now we are fighting another xenophobic policy. Now we are trying to figure out a new way forward. What Stefano Harney and Fred Moten call "the social world of study" has expanded such that, conceived more than a year ago, what is current about this issue of $I V C$ has been altered in ways that many of the contributions, largely written before recent upheavals, here show, especially when read in conversation with one another and with Carby. 6 Those include one short essay on archives, "The National Archives," and one long essay, "Black Futurities: Shape-Shifting beyond the Limits of the Human," by Carby herself, alongside an extended interview conducted with her at UR in 2019; three essays in dialogue with Carby's writing respectively on dreaming, haunting, and migrating; two responses to her archival essay, respectively focused on Blackness in the Mexican archive and the possibility of an "archival-futurism" inspired by Afrofuturism; a cluster of six essays on Black Studies now that arose out of and in response to the roundtable during Carby's visit; and a series of meditations from colleagues and students of Carby about their relationship to her.

One of those meditations, "Studying with Hazel Carby," is a letter from Heather V. Vermeulen to her mentor. In keeping with Carby's own thinking, Vermeulen begins her epistle with a critique of the term "currency" that appeared in our original title for this issue, "Black Studies Now and the Currency of Hazel Carby." As she observes, "currency" has two axes that we need to question when paired not only with Hazel Carby but also Black Studies now: money and commodification, and popularity and presentism. Speaking of "the currency of Hazel Carby," Vermeulen reminds us, hazards commodifying not only the work of a Black feminist scholar, but also the scholar herself, calling to mind the violently financial history of the Atlantic slave trade. $\underline{7}$ In addition to the spectacular axis of racial capitalism that "the currency of Hazel Carby" suggests, Vermeulen points out that the phrase further hazards reducing Carby's work to being "popular and of-the-moment-symptomatic of the times, as opposed to diagnostic, prescient, and seeking alternative futures." For Vermeulen, Carby's work 
only has "currency" to the extent that the concept "denotes that which is immanent and imminent in the lives of those targeted by the market in its current manifestations, in which even ostensibly anti-racist, anti-sexist pockets of academia may be complicit."요 As a result of Vermeulen's incisive reminders, we changed course. For it is insurgency, not currency, that defines Hazel Carby. She is oppositional, anti-ideological, even revolutionary. While this moment, right now, might occasion Carby to write an essay or give a lecture or take an action, when she does, she is not doing so to be au courant. She is instead writing, speaking, and taking action with a will optimistic enough to contend that, even under the direst of contemporary circumstances, we can challenge the present order of things, including through our accounts of the past and our visions of the future. Despite this optimism, she nonetheless asks us to be skeptical of the common sense of this moment, right now, especially as we face crisis and catastrophe at innumerable levels. .9 If there is "currency" to Carby's career, in other words, then it is actually counter-currency. Countercurrents "in thought, in practice, in politics," to borrow a trio of terms from "Black Futurities," distinguish her career, which she has figured as "my flameproof bodysuit, the retardant, skills honed in research, sprayed on a surface toughened with feminist theory." 10 With these countercurrents-a figure that we hope evokes the Black Atlantic as theorized by Paul Gilroy, wake work as modeled by Christina Sharpe, and the shoal as conceptualized by Tiffany Lethabo King-Carby assumes her bodysuit and disrupts the commodified flow of the racialized present that not only pulls contemporary life into its currents, but has also saturated life since the onset of modernity. $\frac{11}{1 n}$ combination with the thinking and writing of countless Black Studies scholars past and present, the countercurrents of Carby's career are like an oceanic gyre: they create a complex system of eddies and whirlpools, of fluxes and flows, which challenges the singularly depressing direction in which we seem, all too often, to be relentlessly pulled as if by a riptide.

In this essay, we name four countercurrents circulating in Carby's career that we see as important to not getting pulled under by that riptide:

1. Gender is not essential but material and historical. So are race, class, and sexuality, with which gender exists in an articulated hierarchy that we must analyze as being at cultural work in the politics of representation.

2. Solidarity is only ever hard won because it requires us to forge alliances in our intellectual and political praxes attuned to the historical specificity of race, gender, sexuality, and class as unequally and antagonistically positioned subjects experience these forces. 
3. Texts cannot replace people; bodies and bodies of knowledge are not reducible to one another; and universities must grasp where they are racially and socially located.

4. We must imagine a future in relationship to the past, making both futurity and historicity elemental features of how we think and act in the present. 12

Briefly describing each of these countercurrents, we trace their relationship to the present, to the essays gathered together here, and to Black Studies now. These descriptions are too brief, given the complexity of not only each countercurrent, but also Carby's career in general. However synoptic, each description takes account of "the battles over the future racial formation" unfolding locally, nationally, and globally in 2020. $\underline{13}$ While we don't take up all of her writing, we engage a range of material from the 1980 s to the 2020 s as "living thought." 14 The current conjuncture means it is well worth giving that thought-the influences, claims, premises, analyses, styles, and stakes to be found in it, and the practices and politics to which these are connectedroom to breathe.

$* * *$

\section{Countercurrent 1}

Raised and educated in Great Britain by a Welsh mother and Jamaican father, as she charts in Imperial Intimacies, Carby is one of the key scholars who brought British cultural studies to the United States in the late twentieth century, especially as Stuart Hall shaped it at the Centre for Contemporary Cultural Studies (CCCS) at the University of Birmingham in the United Kingdom. She was also central to introducing the feminist analysis of race and gender into cultural studies at CCCS, especially as it explored the politics of representation, a major arena of debate in the 1980s and 1990s. As Dennis Dworkin documents in Cultural Marxism in Postwar Britain: History, the New Left, and the Origins of Cultural Studies, Carby departed from "the class model that had inspired the Centre's earlier work," and "articulated a complex, nonessentialist conception of social and cultural identity that extended, rather than broke with, the cultural Marxist foundations of cultural studies." $\underline{15}$ Carby's conception was more of a break at CCCS than Dworkin suggests, especially if we recall that Hall, Carby's teacher, saw breaks within cultural studies as those fractures "where old lines of thought are disrupted, older constellations displaced, and elements, old and new, regrouped around a different set of premises and themes." 16 This is certainly what Carby-along with comrades from CCCS such as Paul Gilroy, Errol Lawrence, and Pratibha Parmar in collections such as The Empire Strikes Back: Race and Racism in 
70s Britain-did in both UK and US contexts alike, ushering in what Dworkin rightly calls "a new theoretical phase" for cultural studies in the closing decades of the twentieth century. $\underline{17}$

That new theoretical phase isn't novel to us anymore. In the study of race and racism, it has been subject to breaks from scholars working on Black ontology, the racial lacunae of archives, the critique of multiracial coalitions, and interracial aesthetics. But that earlier phase warrants recollection because the countercurrent it stirred up prefaced these later breaks, giving rise to more flows and fluxes in Black Studies now. That countercurrent is: Gender is not essential but material and historical. So are race, class, and sexuality, with which gender exists in an articulated hierarchy that we must analyze as being at cultural work in the politics of representation.

No book encapsulates this countercurrent more than Reconstructing Womanhood: The Emergence of the Afro-American Woman Novelist, which Carby published in 1987 (the same year, strikingly, that Hortense Spillers published “Mama's Baby, Papa's Maybe: An American Grammar Book"). $\underline{18}$ Tracing womanhood as a vexed terrain of cultural contestation from the antebellum era to the turn of the twentieth century in the US, Carby declares at the outset of her book that she will reconstruct those historical occasions when "women in general and black women in particular [gained] a space for themselves in which they could exert a political presence." $\underline{19}$ Such presence is never uncomplicated and always contested in the genealogy of representation Carby delineates from Harriet Jacobs and Frances Ellen Watkins Harper to Jessie Fauset and Nella Larsen. For example, at the end of Reconstructing Womanhood, Carby calls into question the canonization of Zora Neale Hurston, since, for her, Hurston "epitomized the intellectual who represented 'the people' through a reconstruction of 'the folk' and avoided the class confrontation of the Northern cities," to which Black people were migrating at the start of the twentieth century, bringing working and middle class African Americans into fraught contact. As Carby argues, "Fauset and Larsen, however, wrote more directly out of this urban confrontation." In her 1928 novel Quicksand, contends Carby, Larsen "refused the resolutions offered by [a] developing code of black middle-class morality at the same time as she launched a severe critique against the earlier but still influential ideology of racial uplift," tearing "apart the very fabric of the romance form" of the novel to invent "the first truly sexual black female protagonist in Afro-American fiction." $\underline{20}$ As these accounts of Hurston and Larsen show, representation in Reconstructing Womanhood has a politics of race, gender, sexuality, and class to it, though politics are never reduced to representation in 
Carby's work writ large. Here those politics are due to, as Carby writes, "the discontinuities and contradictions" that unfold as intellectuals, artists, and writers pursue "creative practices" in which they often self-consciously assume responsibility "for the representation of 'the race." "21

Critique, confrontation, refusal, discontinuity, contradiction. Carby's vocabulary indicates that she is herself in search of the countercurrents of Black cultural history. As Saidiya Hartman and Tina Campt write, that search in Reconstructing Womanhood leads her to writers and intellectuals who fought against the banishment of "black women from the category of woman and [...] the racialized exclusions of humanist discourse. $\frac{22}{2}$ This search was central to Reconstructing Womanhood creating a countercurrent in the 1980s and 1990s that, in addition to its challenge to the class model at CCCS, demanded that African Americanist scholarship and Black feminist theory embrace a materialist perspective over and against literary canons and racialsexual essences that assume experiential continuity among Black women, Black writers, and Black critics as transhistorically the same across time and space. $\underline{23}$ (She would embark on a related project about Black masculinity with the publication of her 1998 book Race Men. $\frac{24}{4}$ ) From that perspective, Carby reconstructed the study of African American culture on the premise that race, gender, sexuality, and class all articulate intricately with one another in both historically specific and hierarchical ways mediated by cultural forms. In this "articulated hierarchy," race is a modality through which gender is lived, sexuality a medium through which class is lived, and culture is an embattled site in which the intricacy of their often contradictory articulation sometimes gets resolved, and other times refuses resolution in what might be an impasse. $\frac{25}{}$ Also from that perspective, Carby pushed back on what she saw as the problematic essentialism of some Black feminist theory. She advocated that "black feminist criticism be regarded critically as a problem, not a solution, as a sign that should be interrogated, a locus of contradictions," since, to evoke the contemporaneous "Mama's Baby, Papa's Maybe," this confounding locus is where Black women historically find themselves materially and discursively, again and again. $\frac{26}{}$

A major leap forward in the 1980s, this first countercurrent has arguably become mainstream, if by a name different than articulation: intersectionality. The articulated hierarchy of race, gender, sexuality, and class in Carby rhymes with intersectionality as the legal scholar Kimberlé Williams Crenshaw elaborated it in a foundational essay published just two years after Reconstructing Womanhood in 1989, “Demarginalizing 
the Intersection of Race and Sex: A Black Feminist Critique of Antidiscrimination Doctrine, Feminist Theory and Antiracist Politics." 27 This is not the place to compare Carby's and Crenshaw's models in detail. But that both of them, along with Spillers, focus on where race and gender meet for Black women in particular points to the wider feminist context of which the first of Carby's countercurrents was an elemental part in Black Studies during the late twentieth century.

By the early twenty-first century, that countercurrent may seem like-but isn't reallyold news. Recalling it here allows us to point to how Black Studies has, to evoke Sharpe once again, developed in the wake of the model of articulated hierarchy as Carby mobilized it. Whereas the theoretical model of articulated hierarchy is congruent with intersectionality, for instance, it is distinct from the models that Sharon Patricia Holland, Frank B. Wilderson III, and Darby English adopt in books published since the turn of the millennium, respectively, Raising the Dead: Readings of Death and (Black) Subjectivity (2000), Red, White, and Black: Cinema and the Structure of US Antagonisms (2010), and To Describe a Life: Notes on the Intersection of Art and Race Terror (2019). A decade separates the publication of each of these brilliant books, which are anywhere from a partial to a paradigmatic departure from the model of articulated hierarchy that Carby's work uses. Whatever departure they represent, whatever new flows they introduce into Black Studies now, they all suggest how a countercurrent from the past meets up with the flux of the present, which various contributors to this issue chart both explicitly and implicitly in their essays.

On the one hand, the work of Holland and Wilderson is characterized by an ontological position focused on a paradigm of Black (non)being from a variety of angles ranging from the strongly pessimistic to the skeptically optimistic with regards to the possibility of Black life. Wilderson contends that for hundreds of years, to be Black has been to "stand as socially dead in relation to the rest of the world." This standing has complex effects on Black life, as in Holland's argument that while Black subjectivity is a "viccissitudinous 'space of death" in its relation to "external hegemonies like whiteness," this space also envelops "queer subjects," especially "black gay and lesbian subjects in relationship to internal communities." $\underline{28}$ Matthew Omelsky more completely describes this ontological pole in relation to Carby in his essay for this issue, "Being and Becoming: The Grammar of Black Theory." We would add to Omelsky's essay that, as Chris Chen has described in "The Limit Point of Capitalist Equality: Notes towards an Abolitionist Antiracism," some scholars in this vein see the ways in which CCCS took up Antonio Gramsci's concepts, especially hegemony, as 
inadequate for accounting for the gratuitous terrors of anti-Black modernity. $\underline{29}$ The ontological position also materializes in Jerome Dent's "Athazagoraphilia: On the End(s) of Dreaming," which explores how our belief that the imagination is an infinite space of endless being fails to remember that the "freedom dreams" of Black cultural and political history are inseparable from the lived experience of social death and racialized finitude.

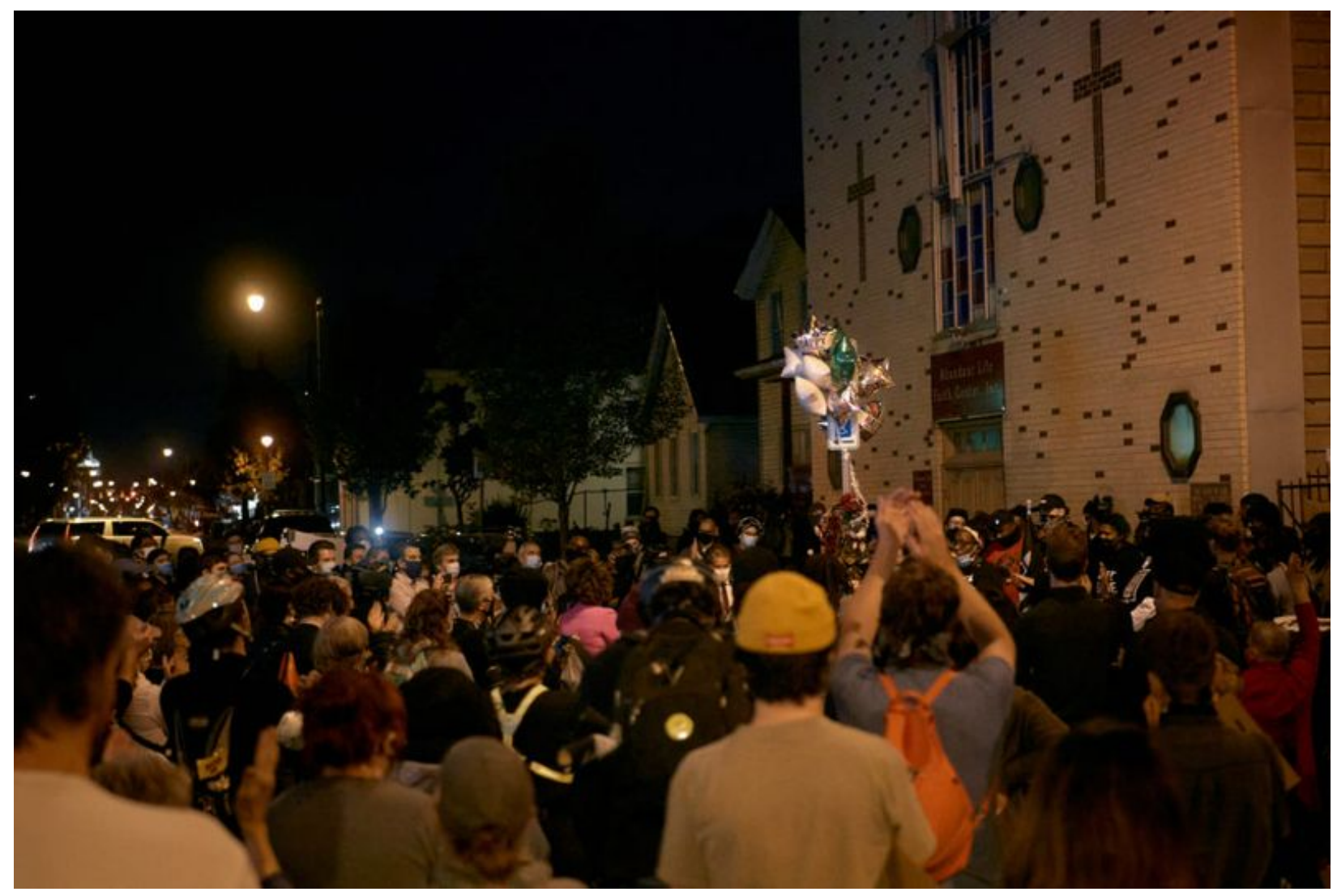

Figure 3: Protest at the site of Daniel Prude's murder on Rochester's Jefferson Avenue. Photo by Martin Hawk, part of Pressure Gradient.

On the other hand, there are also positions less paradigmatically far-reaching-if still meaningfully heterodox-than the rich thinking on Black ontology that is necessary reading at present. In the work of English, for instance, the critical aim is to be more "informal" in one's encounter with race and racism, especially by way of art and culture that propels aesthetic subjects looking at a painting or contemplating a sculpture into what he calls states of "discomposure." For the critic, he asserts, such discomposure inspires "a strategy [that] seeks to explain how certain objects engaging questions about the representational politics of the present do so in a way that actually keeps those questions open. It imagines not a formless politics, but a politics informal enough to engage with equal seriousness the letter and the spirit of a question."픔 
Much as contemporary scholarship on Black ontology is salient to how Omelsky and Dent are in dialogue with Carby, English's informal politics has a bearing on the politics of susceptibility that Anne Anlin Cheng sees in Carby's career and advocates more widely in "Susceptible Archives," her meditation on Imperial Intimacies for this issue. Together, Cheng, Dent, and Omelsky draw out the eddying complexity of Black Studies now as it has stirred things up in response to the first of the countercurrents we have identified in Carby's writing and thinking-a countercurrent that, as the work of Holland, Wilderson, and English suggests, has generated contrasting thought, practice, and politics for navigating the present.

\section{Countercurrent 2}

The theoretical model of articulated hierarchy cannot be disentangled from the practical model of solidarity in Carby's career. The first countercurrent we find in her career thus flows into the second one: Solidarity is only ever hard won because it requires us to forge alliances in our intellectual and political praxes attuned to the historical specificity of race, gender, sexuality, and class as unequally and antagonistically positioned subjects experience these forces.

This countercurrent is most prominent in Carby's accounts of those who get excluded from certain models of class struggle and feminist sisterhood: Black people, especially Black women. In Reconstructing Womanhood, for instance, Carby critiques a model of solidarity that "assert[s] the necessity for white and black to sink their differences and unite in a common and general class struggle." $\underline{31}$ This critique takes a compellingly inverse shape in her writing on blues culture, especially her amazing 1992 essay "Policing the Black Woman's Body in an Urban Context." Carby analyzes how a Black bourgeoisie in places like Chicago and New York and Black working-class women migrating to Northern cities came into class conflict through gender and sexuality in the early twentieth century. Blues singers such as Ida Cox and Mamie Smith "brought to the black, urban, working class an awareness of its social existence and acted creatively to vocalize the contradictions and tensions of the terrain of sexual politics in the relation of black working-class culture to the culture of the emergent black middle class. "르 The theoretical model of articulated hierarchy is operative in Carby's analysis of Cox and Smith, in which race, gender, sexuality, and class get contradictorily and confrontationally lived through one another in cultural form. In this issue, Patrick Sullivan extends the insights of "Policing the Black Woman's Body" in "Get Down: Funk, Movement, and the End of Great Migrations," which is also in dialogue with Carby's 1987 essay “The Sexual Politics of Women's Blues.” $\underline{33}$ Here, though, we want 
to stress that the model of articulated hierarchy cannot be separated from a model of solidarity that does not subsume the antagonisms of race, gender, class, and sexuality as key to the ground upon which power gets built. Theory flows into praxis, both intellectually and politically, in the countercurrents of Carby's career.

Notably, a language of voice and voicing sometimes rings out in Carby's thinking and writing on praxis, as in the above when she aptly speaks of Black women singers who vocalized the contradictions of sexual politics rather than subsuming them in the name of bourgeois ideology. This account of blues women and their praxis recalls, for us, the resistant and resonant voice with which Carby spoke at UR in winter 2019. Even more, though, it brings to mind one of her most polemical statements on solidarity, "White Woman Listen! Black Feminism and the Boundaries of Sisterhood" (1982), which possesses a multiracial conception of Black women's experience that was silenced in feminist calls for sisterhood in 1970s Britain. $\underline{34}$ This was because that "sisterhood" revolved around middle-class white women with almost no theoretical or practical consideration of the African, Asian, and Caribbean women who were, throughout that decade, "fighting, in the streets, in the schools, in the courts, inside and outside the wage relation" as Black women. $\frac{35}{}$ Carby insists that this critique should not be heard as a call for "teams of white women [to] descend upon Brixton, Southall, Bristol, or Liverpool to take black women as objects of study in modes of resistance" in a manner that replicates the racist and colonialist logics of the increasingly post-imperial British state. $\frac{36}{}$ Instead, she states, “The [Women's Liberation Movement needs] to listen to the work of black feminists and to take account of autonomous organizations like OWAAD (Organization of Women of Asian and African Descent) who are helping to articulate the ways in which we are oppressed as black women." $\underline{37}$

The critique in "White Woman Listen!" echoes a question that Toni Morrison posed in 1971: "What do black women feel about Women's Lib? Distrust. It is white, therefore suspect." $\underline{38}$ Writing out of distinct national contexts, Morrison and Carby nonetheless both express a deep uncertainty about alliances between Black and white women given the racial exclusions of feminism in the 1960s and 1970s. Carby in particular highlights that white women must be regularly willing to be quiet when Black women speak in their own voices if feminism is to be liberatory. It is only once such voicing habitually occurs that, to borrow from a lecture that Audre Lorde delivered in Chicago in 1977, the transformation of the specific forms of silencing that white and Black women have unequally experienced will provide the language and action necessary for what will still be hard won feminist solidarities. $\underline{39}$ More widely, then, Carby advocates 
a practice of solidarity in which unequally and antagonistically positioned historical subjects forge-in which they collectively articulate-what she elsewhere calls a "system of alliances" by first listening to one another, both intellectually and politically. $\underline{40}$ We listen not simply to have a dialogue, especially since dialogue alone only goes so far, as Alanna Prince and Alisa V. Prince address in their contribution to this issue, "What's Haunting_Black Feminism?" We listen in order to move onto the difficult work of transformative thought and practical action, including the work of interrogating, as the question with which "White Woman Listen!" closes does, just who "we" are. $\underline{41}$

Without trustworthy listeners, we cannot have responsible voices, much less anything like a collective voicing of protest and power. Generated forty years ago, this countercurrent in Carby's work remains one today. At the still ongoing protests of 2020, chants such as "WE. CAN. NOT. BREATHE" raise questions about who "we" are and for whom "we" chant in the multiracial coalitions that have assembled at Black Lives Matters actions. Has the necessary dialogue taken place? Has the difficult process of listening and articulating unfolded such that transformative thought is the basis of action? Does the activism of allies primarily serve their self-image, or is it the effect of the struggle to mobilize beyond the self? Are we getting next to both ourselves and the selves of others as we "flow inward and outward in the back and forth of interracial conflict," such that interracial solidarity is a genuinely collective countercurrent against racism in its psychic and political articulations alike? $\underline{42}$ 


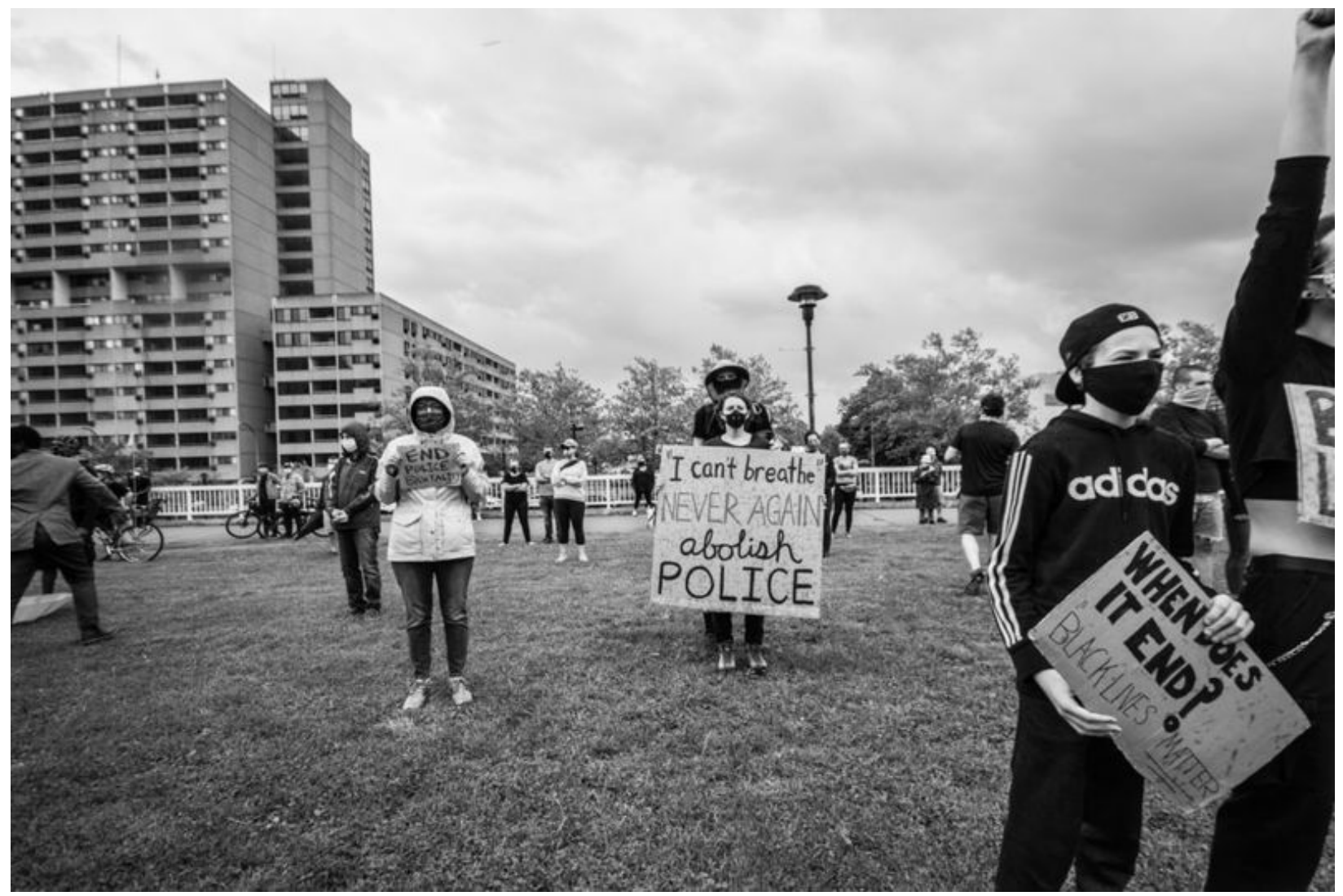

Figure 4: Protest by Manhattan Square, Rochester NY, May 2020. Copyright Erica Jae.

These questions about who we are and for whom we chant are vexed further at present in one direction by the ostensibly universal but actually racist appeal that "All Lives Matter," and in another direction by the need to specify that "All Black Lives Matter." Where the "all" of the former is anti-Black code for white people and the so-called "blue lives" of the police, the "all" of the latter is declaring that, in the difficult solidarities we labor to articulate, the lives of Black trans and queer people, Black incarcerated and formerly incarcerated people, Black men and women, and Black children in formation need to be centered. Evidence of the need for this declaration is clear in both public and private at the moment, including on Rochester streets, where in July of this year a local transgender Black Lives Matter activist was brutally beaten. $\frac{43}{}$ It is also clear in the domestic space of Black homes, as Carby has movingly shown in "Safe? at Home?" In this essay, she recalls her own history of protest in London around the insecurity of "home" for Black Londoners, and she memorializes a series of Black women murdered by police from the 1980s to the present while in their own houses: Dorothy (Cherry) Groce, Cynthia Jarret, Joy Gardner, Breonna Shaquille 
Taylor, Atatiana Koquice Jefferson, Deborah Danner, Tarika Wilson, and Eleanor Bumpers. $\underline{44}$

The second countercurrent also has a bearing on contemporary campuses, where solidarity is just as hard won as anywhere else, if in ways that require us to imagine the distinct shapes specifically academic solidarities might take in the effort to interrupt the so-called "normal" order of things in higher education. This was the point of the Scholar Strike for Racial Justice of September 8 and 9, 2020, in which more than 500 people at UR participated in a variety of individual and collective ways along with many others nationwide in the US. These ranged from opening up classes relevant to thinking about racial justice and halting work at the institution not grounded in an antiracist ethos to student-led conversations about better forms of public safety, a screening of the film, July '64, that historicizes the current situation in our city, and local activists educating faculty, students, and staff about how to get involved in transforming Rochester. $\underline{45}$ It is also the point of at least three essays in this issue. In "Black Studies in Haudenosaunee Country," Brianna Theobald charts how academic solidarity might arise on campus at the nexus of Black Studies and Native Studies, especially if we "foreground those moments, however fleeting, when Black Americans and Native Americans—not mutually exclusive categories-formed alliances and coalitions in defiance of the federal government's and white settlers' attempts to divide them." And in "Attuned Within, Attuned Without: Hazel Carby and the Lessons of Leadership,." a title that echoes Carby's language of voice and voicing, Michelle Ann Stephens contends that university leaders must be willing to build academic solidarities by "finding the balance between listening to oneself and projecting one's thoughts outward, so they can have an impact on the social world" of which an institution of higher learning is a part.

The Scholar Strike, the coalition of Black Studies and Native Studies, and academic leadership as a dynamic of social attunement are all examples of efforts to imagine and enact academic solidarities at present on frequencies to which Carby has been attuned throughout her career, whether through Black feminist interventions or labor politics in higher education. $\underline{46}$ These examples point, moreover, to what is explored in the third essay in this issue germane to the second countercurrent, Cilas Kemedjio's “Black Studies and the 'Ideology of Relevance.'" Kemedjio assays the ideology of relevance that galvanized the rise of Black Studies in both African countries and the US in the 1960s, where political militancy and community-engagement were woven into, in his 
phrasing, the "scandal" of Black Studies in universities around the world. That scandal is the subject of the third countercurrent.

\section{Countercurrent 3}

The Department of African American Studies at Yale University came about in no small part through the labors of Carby; she built a system of alliances that considered faculty, students, and staff in its vision of what education could be. That vision, as an article covering Carby's retirement from Yale in June 2019 reports, "was to create an interdisciplinary and multidisciplinary Ph.D. program to ensure that Yale's graduate students were well trained for the job market and were well prepared to become leaders in the field. She also expanded the curriculum to encompass more of the diaspora by including Europe, the Caribbean, Latin America and the Atlantic World."쓰 Refusing a narrow US focus, this kind of training occurs in the undergraduate degree as well. $\underline{48}$ In its interdisciplinary and multidisciplinary scope, this vision reflects, as Stephens remembers in her essay for this issue, "Hazel's sense that African American Studies was an epistemological and methodological undertaking that critically engaged the entire apparatus of knowledge production." Students in the Combined Ph.D. in African American Studies, for instance, develop a course of study with another department or program, including American Studies, Anthropology, English, Film and Media Studies, French, History, History of Art, Music, Political Science, Psychology, Religious Studies, Sociology, Spanish and Portuguese, and Women's, Gender, and Sexuality Studies. $\underline{49}$

Recalling the interdisciplinarity of CCCS, the Department of African American Studies that Carby helped to build rejects the domestication and atomization that traditional disciplines sometimes demand. Such institution building, of course, mobilized more traditional resources such as the academic department to create a catholic space of intellectual praxis that, for Carby, not only engaged the entire apparatus of knowledge production, but also the place of that apparatus within a wider racial-ethnic order and social-economic formation. This gets us to the third countercurrent we see in her career: Texts cannot replace people; bodies and bodies of knowledge are not reducible to one another; and universities must be accountable to where they are racially and socially located.

The claim that texts cannot replace people eddies through Carby's "Dispatches from the Multicultural Wars," one of the constellations of essays from the 1980s and 1990s that make up her 1999 volume Cultures in Babylon: Black Britain and African America. 
A high school teacher in a multiracial and multiethnic borough of London before matriculating at CCCS in the 1970s, Carby started issuing these dispatches as early as 1982 with "Schooling in Babylon." $\underline{50}$ It is her two-part series from the early to mid1990s, "The Multicultural Wars," that diagnoses a problematic relationship between texts and people in education. She argues that in many literature departments "black cultural texts have become fictional substitutes for the lack of any sustained social or political relationships with black people in a society that retains many of its historical practices of apartheid in housing and schooling." $\underline{51}$

This is part of a wider problem in higher education especially in Carby's view. “Departments and programs in many private universities," writes Carby in 1992, “will proudly point to an 'intergrated' curriculum while being unable to point to an integrated student body-except in photographs [...] that contrive to demonstrate 'diversity' by self-consciously including the pitiful handful of black, Latino, Asian, Chicano, and perhaps even fewer Native American students on campus." Moreover, the textual and photographic displacement of an integrated student body parallels data revealing "the paltry presence of non-white regular faculty in universities." $\underline{52}$ Carby was not arguing that the curricular changes associated with multiculturalism in the late twentieth century should not have taken place, nor would she suggest now that we should not be trying to desegregate and decolonize our syllabi. Instead, she was arguing what remains an ongoing issue today, that these curricular changes ought to involve efforts to desegregate-and, we would add, decarcerate-higher education by recruiting and retaining Black, Latinx, Asian, Native American, and incarcerated and formerly incarcerated students and faculty. A query stickered and re-stickered on a door in Morey Hall on the UR campus in September 2019 summed up the problem aptly, asking anyone who read it as they headed to class: "WHERE ARE ALL THE BLACK PEOPLE AT?” (fig. 5). 


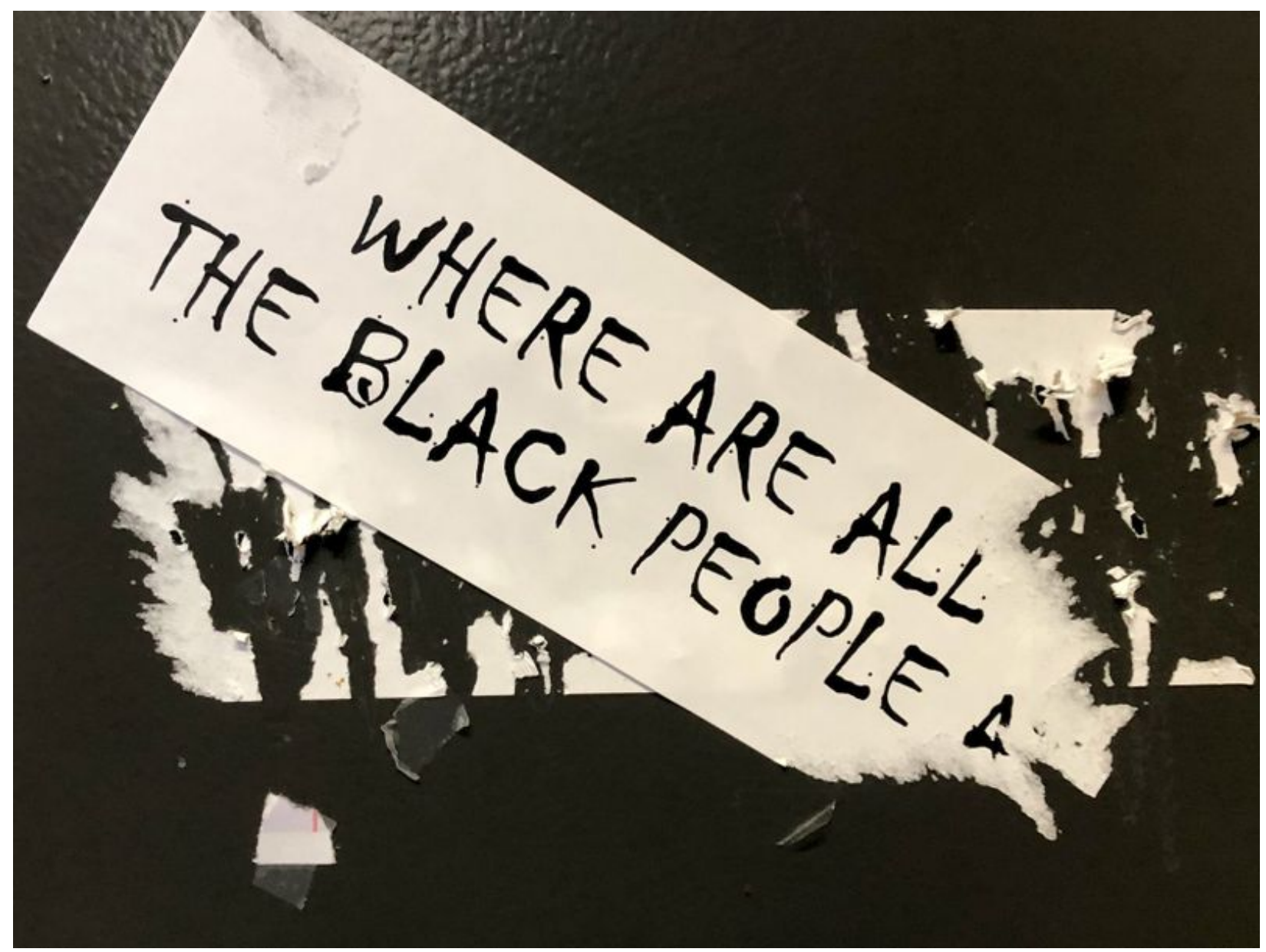

Figure 5: "WHERE ARE ALL THE BLACK PEOPLE AT?" Sticker intervention at the University of Rochester. Photo by Joel Burges.

Crucially—or, to recall Kemedjio, scandalously—such efforts to desegregate and decarcerate must refuse to "ghettoize" the study of race, ethnicity, and indigeneity by rejecting the idea that "fields of knowledge [can be] reduced to specific imaginings of bodies in particularly insidious ways," that bodies and bodies of knowledge, in other words, can be reductively conflated. $\underline{53}$ But instead, education must be reconstructed around the idea that, as she writes in "The Multicultural Wars: Part One":

everyone in this social order has been constructed in our political imagination as a racialized subject. In this sense, it is important to think about the invention of the category of whiteness as well as of blackness and, consequently, to make visible what is rendered invisible when viewed as the normative state of existence: specifically the white point in space from which we tend to identify racial difference. If, instead, we situated all North American peoples as racialized 
subjects of our political imagination, we would see that processes of racialization influenced all of our work. $\underline{54}$

To frame Carby's point in terms of our own institution, it is just as important for Physics \& Astronomy at UR to recruit African Americans, as they have made a plan to do, as it is for the Frederick Douglass Institute of African and African American Studies (FDI) to expand its faculty. $\underline{55}$ This kind of cross-disciplinary scholarly recruitment should happen in tandem with FDI growing the study of race, ethnicity, and indigeneity at $\mathrm{UR}$, as the combined $\mathrm{PhD}$ program at Yale readily shows is possible as a model for us to pursue into our future. Then the answer to the stickered query above might be: "EVERYWHERE." But this answer can only be voiced if we keep struggling for the expansively multiethnic and multiracial transformation of education for which Black Studies can be one point of departure now.

Kathryn A. Mariner elaborates these points in her powerful essay for this issue, “On Needing_Black Studies," in which she observes that she has a "sideways" relationship to the field, having taken many courses on race during her education, but none specifically on Blackness. It is from this lateral angle that Mariner keeps the third countercurrent in Carby's thought flowing in the here and now, funneling it into our present by way of her own position as an anthropologist invested in "frameworks like Black geographies and disaporic space to make sense of what I am finding on the ground in a postindustrial context where deep histories of racism continue to shape both social and built environments." Elaborating the contention that bodies and bodies of knowledge are not reducible to each other, and extending the claim that all of our work needs Black Studies, Mariner takes up the challenge that Carby further poses in "The Multicultural Wars: Part Two." There, Carby insists that we need to advance from "cultural forms" to "cultural formations" by accounting for the place-the racial and social location-of our universities in them. $\frac{56}{}$ As Mariner writes, "Black Studies in the university must translate to Black Studies beyond the university." 


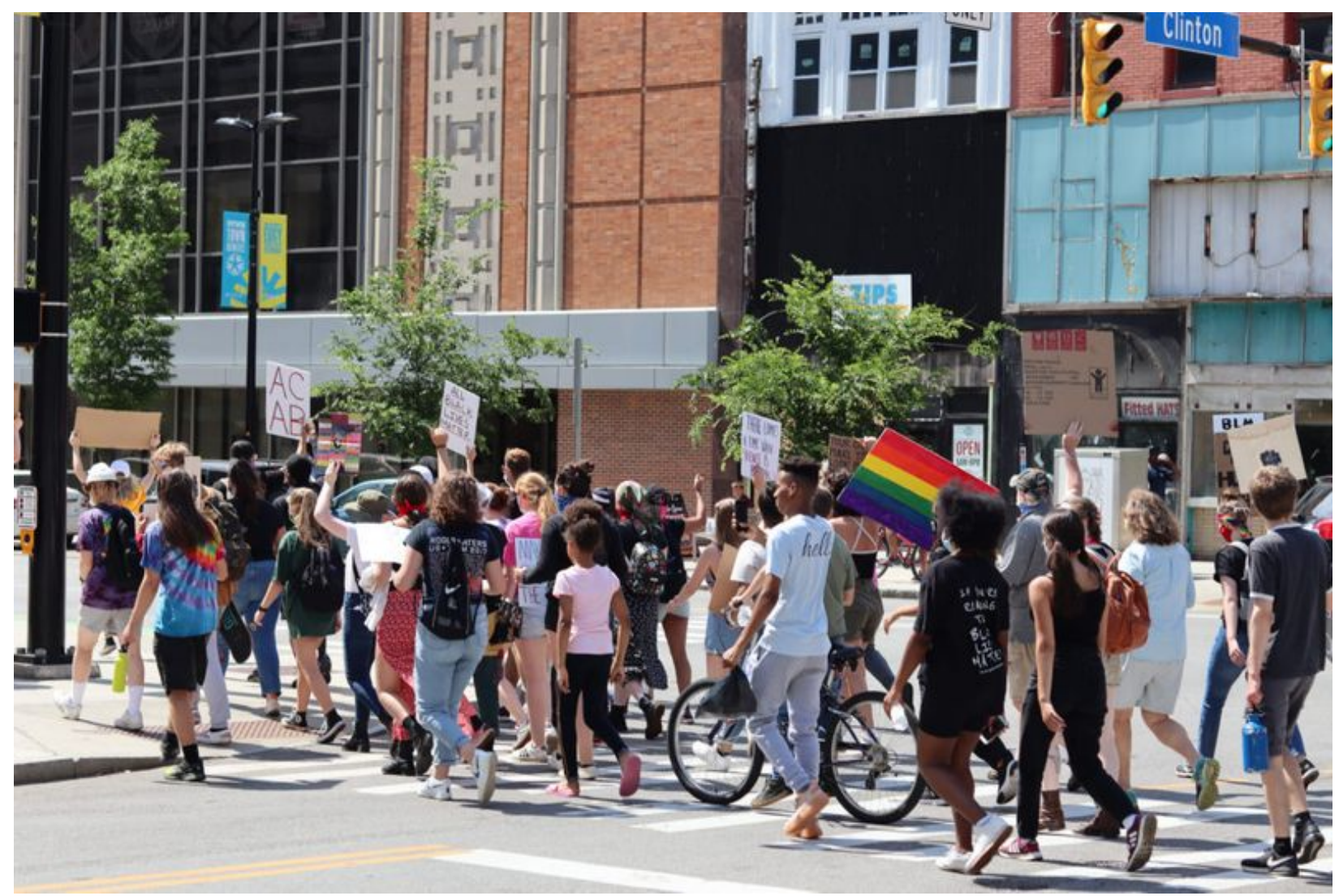

Figure 6: A group of student protesters marching to Rochester City Hall on June 29, 2020. Photo by Quajay Donnell.

This is true for all of us at the University of Rochester. Our institution sits in a deeply segregated and thoroughly carceral landscape in upstate New York. In light of this situation, it needs to play a stronger role in redressing the racially based poverty to which it contributes in Rochester, as Bruce E. Popper, an alumnus of UR and a leader of its service workers union (1199 SEIU United Healthcare Workers East), has recently argued in an open letter to UR President Sarah Mangelsdorf and UR Medicine CEO Dr. Mark Taubman. $\frac{57}{1 t}$ is also, as Theobald observes, "located on the ancestral homelands of the Seneca nation of the Haudenosaunee Confederacy," pointing to the long history of racialized displacement that shapes UR. Finally, it is intertwined with the globe as well. At UR students from Asia, Africa, Europe, and Latin America face an educational context that often operates differently along the fracture lines of race and ethnicity than elsewhere in the world; these students have experiences that intersect in always complicated and sometimes-painful ways with race and racism in the US. Rochester is itself a study in the racial and ethnic fluxes of the world. With a spatial history rooted in the Seneca nation and European immigration, in addition to its African American population, the city also currently has a large Afro-Caribbean population; a sizeable 
Puerto Rican migrant community; and residents who arrived as refugees from nations that include Bhutan, Nepal, Somalia, and Syria. $\underline{58}$ Taking this cultural formation into account gives us not just a more complete view of the historical and contemporary place of UR in a multiracial and multiethnic community, but also sets us going towards new futures for placemaking in Rochester.

\section{Countercurrent 4}

From her accounts of blues women and race men to her exploration of African American visions of Los Angeles in literary texts, how the future is figured-how alternative social arrangements, queerer forms of subjectivity, and emergent forms of being and becoming are imagined over and against catastrophe as our horizon-is a driving concern of Carby's writing and thinking. In her work, that future is never a guarantee. But it is always arising as a present possibility in relationship to the historical upheavals of any "multi-racial, inter-racial, and multi-ethnic community." $\underline{59}$ This brings us to the final countercurrent: We must imagine a future in relationship to the past, making both futurity and historicity elemental features of how we think and act in the present.

That imagining the past is pivotal to re-imagining the future is clear from Carby's recent turn to the archives of empire in her book of auto-history, Imperial Intimacies: $A$ Tale of Two Islands (2019), a catalogue essay she co-authored with Heather V. Vermeulen for an exhibition they curated together, Prospects of Empire: Slavery and Ecology in Eighteenth-Century Atlantic Britain (2014-15), and one of her two essays for this issue, entitled "The National Archives." If Reconstructing Womanhood was part of the debates about representation that arose in the 1980s and 1990s, then these three texts are part of a present-day dialogue in which the archive as such, especially its ways of assembling, ordering, and categorizing the racial lives of imperial modernity, is what's under discussion. Central voices in that dialogue over the past decade include Ann Laura Stoler in Along the Archival Grain: Epistemic Anxieties and Colonial Common Sense (2009), Tina Campt in Image Matters: Archive, Photography, and the African Diaspora in Europe (2012), Lisa Lowe in The Intimacies of Four Continents (2015), Marisa J. Fuentes in Dispossessed Lives: Enslaved Women, Violence, and the Archive (2016), Daina Ramey Berry in The Price for Their Pound of Flesh: The Value of the Enslaved from Womb to Grave, in the Building of a Nation (2018), Saidiya Hartman in Wayward Lives, Beautiful Experiments: Intimate Histories of Social Upheaval (2019), and Deborah A. Thomas in Political Life in the Wake of the Plantation: Sovereignty, Witnessing, Repair (2019). 
This is a heterogeneous body of work, one characterized by a powerful sense of methodological, historical, and stylistic adventure. In the case of Carby's Imperial Intimacies, it has meant reckoning with the archives of her personal and political past, of her mother's and father's lives within a centuries-long "movement between and among places, spaces and peoples, that scattering that results in racialized encounters and the violent transactions that produce racialized subjects. $\underline{60}$ In the Prospects of Empire essay, it has meant cultivating "archival attention to works that expose practices of erasure and containment, past and present, and to develop linkages-such as those between slavery and ecology_in an effort to think new subjects." $\underline{61}$ In her auto-historical essay for this issue, it has meant describing how, while doing research in the National Archives in the United Kingdom, "As a daughter and granddaughter I was left bereft, dissatisfied and unsettled that lives silenced in and by the archives and by enslavement are irretrievable."

Carby's work has often been archival in important ways, especially if we recall that many of the texts she was analyzing in Reconstructing Womanhood were only just

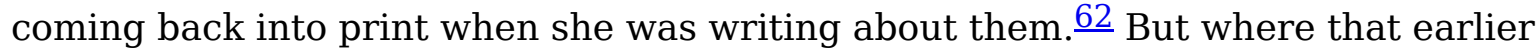
book was concerned with asserting the presence of Black women in cultural history, the texts above are also focused on the politics and poetics of absence in the archive. Following the ideas of Michel-Rolph Trouillot in Silencing the Past: Power and the Production of History (1995), Carby is struggling with the silences and violences of the past in her current writing and thinking. Pablo Miguel Sierra Silva and Miranda Mims join in that struggle in their essays for this issue, respectively entitled " $\underline{\text { Negros, aquuí? }}$ Blacks, here?': Blackness in the Mexican Archive" and "Archival-Futurism: Archives as Social Justice." Taken together, these three essays suggest the traffic between historicity and futurity that circulates in this final countercurrent. What that countercurrent moves us to do is confront-personally and politically, narratively and prosaically, historically and critically, thoughtfully and tactically-the silences and violences of the past as current conditions for the possibility of a future beyond catastrophe, for a collective countercurrent that refuses now as all we have left.

This future is the subject of Carby's other essay for this issue, a tour de force of prose, imagery, and music entitled "Black Futurities: Shape-Shifting beyond the Limits of the Human." Moving between reading, viewing, and listening, “Black Futurities” draws its readers-viewers-listeners into an experimental aesthetics, a style by which Carby, as she does in Imperial Intimacies, strikingly takes leave of traditionally academic prose. $\underline{63}$ Employing a voice as powerful as ever, she poetically raises the questions in 
the epigraph to this introductory essay, questions regarding the impossibility of the future in the face of ecological catastrophe at present, especially as that present envelops Black and Indigenous peoples globally. Her answer refuses a return to a past in which patriarchal control over women and wombs "was a political sign of the entry of black men into modernity." Instead, she remembers, resurrects, reclaims, and recycles - these are her verbs-paintings, pop-up books, and fiction by, among others, Jacob Lawrence, Ellen Gallagher, Kara Walker, and Octavia Butler as "archives of the future in the past" that she insists demand both labor and love. What could come from that labor and love? Black futurities that shape shift beyond the human into an "alternative humanism," that answer environmental disaster with a new ecology of interspecies life, that insist "upon the interdependence of all organisms" as "the essential work in the unfinished project of freedom."

That freedom is an unfinished project of recollection and anticipation-a countercurrent where a disrupted past and an impossible future meet to engender an alternative humanism-is a theme of scholars working both lateral to and directly within Black Studies at present, as in the two following books, both published in 2019. In Contingent Kinship: The Flows and Futures of Adoption in the United States, Kathryn A. Mariner gives us an ethnography of transracial adoption that, in her words, "chart[s] the ebbs and flows of futures-in-the-making, revealing how modes of intimate speculation function to create futures for some, while dissolving them for others." $\underline{64}$ And in Queer Times, Black Futures, Kara Keeling proposes the following: "None of us survives as such; indeed, perhaps, freedom requires we give way to other things. Now. And perhaps again." $\underline{65}$ Like Carby, Mariner and Keeling know that making futures now is an unfinished project on our planet, whether that planet be intimate and local or abstract and global. Together, their work suggests that this project will propel us into the contingencies of kin within and beyond the human, or as Keeling writes, into an "Afrofuturism wherein aliens and others organize social life" according "to the stubborn spatiotemporalities of our senses as a way to intervene in the smooth and seductive assertions of capitalism's inevitability, issued from Capital's predictable futures." $\underline{66}$

Two such interventions appear in this issue, suggesting the whirlpool that has formed around past and future in Black Studies now. In "Extirpation is Not an Option: An Esperantic Vision of a Future for Black Studies from the Other Side of the Pacific," Will Bridges enumerates and celebrates the intellectual yields of attending to the history of Black Studies in Japan, bringing Pacific considerations into the often Atlantic-centric 
vision of Black Studies. The examples that Bridges cites converge with the field of Future Studies, looking ahead in order to create visions for Black life, and to resist its erasure, in the future. Similarly, Darren Mueller's “Black Studies in the Digital Crawlspace" performs close readings of key works from Black musical and literary history, which inform his analyses of Black life online and in digital media, in which scholars do some of the most innovative work in the field today. Mueller also connects the history of race-based slavery and anti-Black racism to online hate speech and the algorithmic re-centering of whiteness and masculinity; however, Black Studies' vital interventions on this contested digital terrain are many and meaningful, due in part to their links to traditional structures of knowledge.

As we bring this essay to a close, we want to return one last time to a chant that has resounded loudly in 2020: “WE. CAN. NOT. BREATHE.” This chant resounds with past and present in at least three powerful ways. It resonates, first, with a past that Carby details in her July 2020 essay "Peine forte et dure" for the London Review of Books. There, Carby describes Floyd's death on video as part of a long genealogy of "de facto, if not de jure, torture, a contemporary enactment of execution by pressing," which is the centuries-long technique of punishment her title names and her essay excavates as a prehistory of the racial present. $\frac{67}{6}$ The chant resonates, second, with the voices of those who have fought against white supremacy for centuries, including the voices of Nat Turner, Touissant L'Ouverture, Sojourner Truth, Ida B. Wells, the Black Panther Party for Self Defense, Malcolm X, Angela Davis, Hazel Carby, and more. They also include the voices of Black people today who are fighting the same fight as their parents, grandparents, and great grandparents. These ancestors taught their descendants what white protesters were not required to learn from childhood onwards: always to be aware that violence awaits them as a potential reality. As in Imani Perry's Breathe: A Letter to My Sons, dedicated to "the ancestors and the children," “WE. CAN. NOT. BREATHE" connects generations of the deceased to the currently living at Black Lives Matters protests in 2020 through a chant that declares Black people are sick and tired of that centuries-old potential. $\underline{68}$ Finally, the chant also resonates with the COVID-19 crisis, in which person-to-person transmission is mainly respiratory, often causing interference with normal breathing. $\underline{69}$ But as Dionne Brand and Ibram X. Kendi have both taught us, joining in this chant is not about returning to a world in which we can all breathe "normally" again; it is about speaking out against a world of "normality" in which blackness and breath are mutually exclusive. It is a 
demand that calls out for more room to breathe freely and flourishingly in a world in which nothing was ever "normal." $\underline{70}$

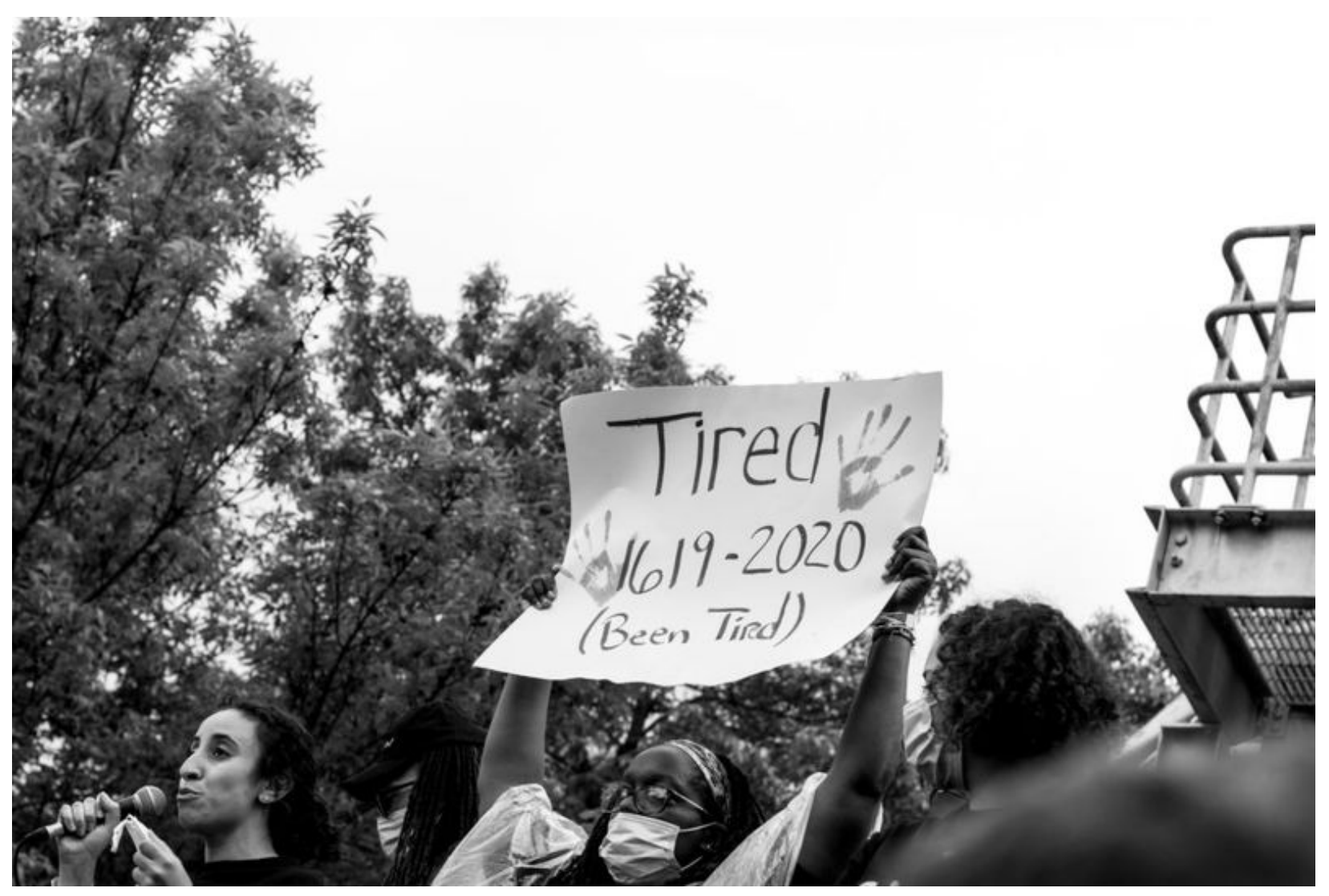

Figure 7: Been Tired, Rochester NY, May 2020. Copyright Erica Jae.

This demand echoes another that can be heard in the title of both this essay and this issue of IVC: "Black Studies Now" - an old demand for many students, staff, and scholars. This is not to say Black Studies is stale and redundant, but rather that the new knowledge, interdisciplinary practices, and ethics of education it asks us to pursue into the future has a history that, as with the countercurrents of Carby's writing and thinking, is necessary to remember. The first Black Studies department was established during the 1967-68 academic year at San Francisco State College as a result of the activism of that campus's Black Student Union. South of San Francisco, in October of 1968, twenty students occupied a building in which vital computer equipment was housed on the campus of the University of California-Santa Barbara, demanding library materials and the creation of a Black Studies department, which was realized the following year. "Between 1968 and 1975 over five hundred academic units (programs and departments) offering Black Studies courses were in place across the country," a development linked to the youth movements of the 1960s and 1970s, including the activism of the Student Nonviolent Coordinating Committee, which 
"were grounded in more fully articulated paradigms of scholarship closely connected to a range of human interests, rather than serving the vested concerns of a narrow stratum of wealth and power." $\underline{71}$

Our university belongs to this history. In March 1969, the Black Students Union occupied two floors of the Frederick Douglass Building for a week, producing demands not unlike the ones that persist today asking for more Black faculty, staff, and students, the expansion of course offerings in Black studies, and an improved relationship with the local Black community. Thirty years later, in 1999, a multiracial group of undergraduate students at UR led another occupation, engaging in a sit-in at the Office of the President and demanding African and African American Studies after such a program had ceased to function during the previous year. This protest led to the rebirth of FDI in its current form. And fifty years later, the struggle continues. In November 2015, representatives from UR's Minority Student Advisory Board, the Black Students' Union, the Douglass Leadership House, and the Spanish and Latino Students' Association presented demands regarding the status of minority students, staff, and faculty, which led to a Presidential Commission on Race and Diversity and a 2016 report on new and ongoing initiatives to address racial issues on campus. When in 2020 President Sarah Mangelsdorf commented on the killing of George Floyd earlier this year, the student-led Abolition Coalition responded by demanding that UR do more than simply make well-meaning statements. Their petition led to an online meeting organized by FDI that brought faculty, staff, and upper administration, including College deans and the President, together to hear directly from students about their ideas on UR becoming an anti-racist university. The Scholar Strike followed the week after the revelation of the killing of Daniel Prude. It was at this time that UR welcomed a new Director of FDI, the result of a national search. That Director, Jeffrey McCune, is charged with guiding FDI through the process of departmentalization, one of the Abolition Coalition's key demands. 


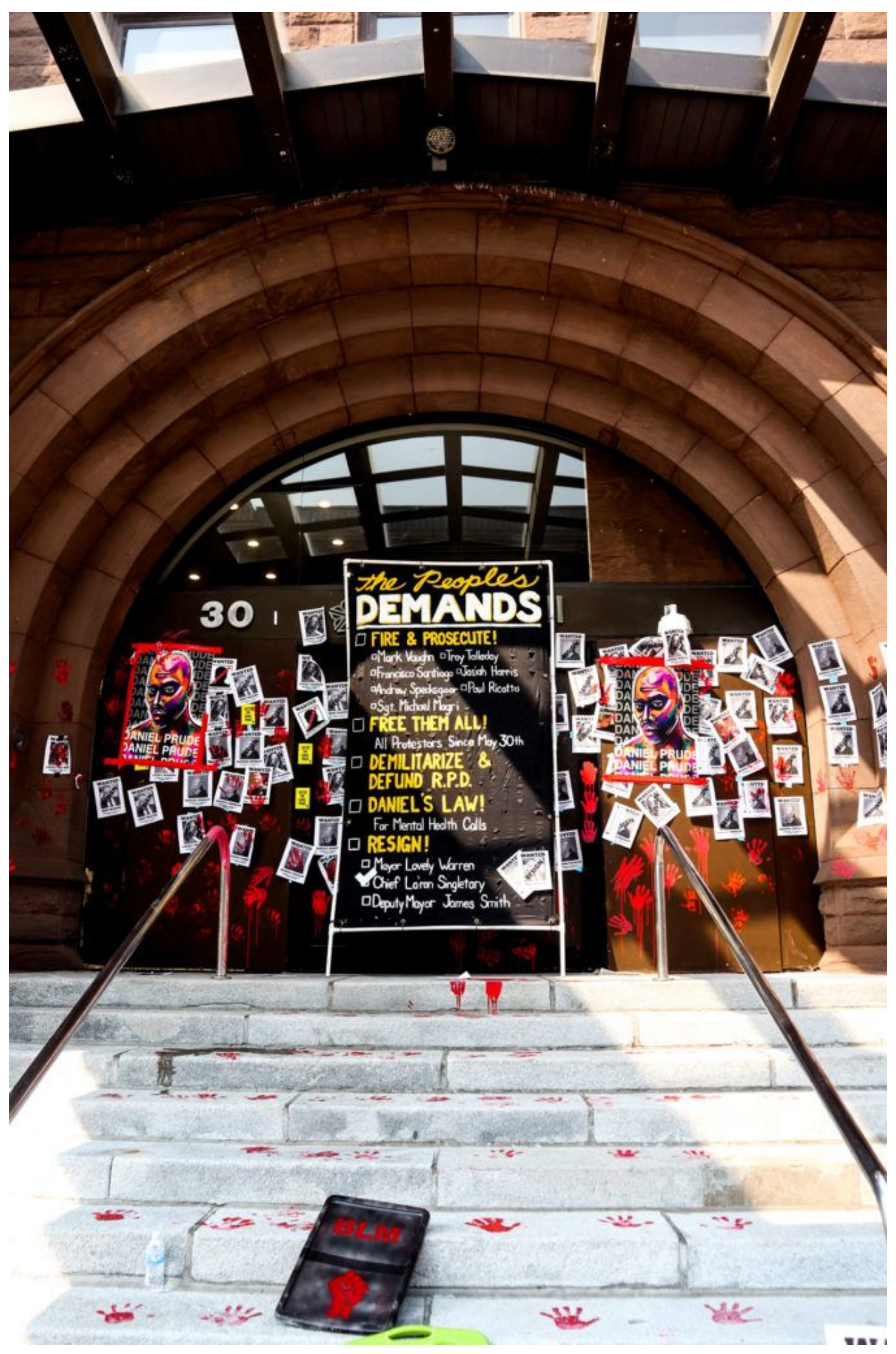

Figure 8: "The People's Demands" posed to the Rochester city government by activist group Free the People ROC during the occupation of city hall in September 2020. Photo by Quajay Donnell.

The University of Rochester, in short, is reckoning with racial justice from top to bottom at present. This reckoning - a term in wide circulation in 2020-includes those 
of us who have seen ourselves as already committed to racial justice but must rethink our theories and reinvent our tactics in order to tune into this moment and its long history anew. In tracing the countercurrents of Hazel Carby to Black Studies now in this introduction and issue, we hope to contribute to that reckoning, rethinking, and reinventing. We hope to draw on the force of those countercurrents in meeting the longstanding demands for an anti-racist UR in a multiracial and multiethnic Rochester. So while the issue looks outward to the thinking and writing of Carby, meeting those demands where we are is a central motive for so many of our contributors being people who work, study, and teach at UR. We have tried to remain rooted in the place where we live, labor, love, and learn in order to confront the limits and possibilities of this place. Once we do, we can begin to face the difficulties of transforming it instead of returning to life as normal.

\section{Acknowledgments}

The authors want to acknowledge the immense amount of labor and participation from students, staff, faculty, and community members at and beyond the University of Rochester that went into the events that led to and the publication of this issue of InVisible Culture. Hazel Carby's visit was sponsored by the University of Rochester Humanities Center of the College of Arts, Sciences, and Engineering as part of its Distinguished Visiting Humanist series, with significant funding from the Office of the President of the University of Rochester. We would like to thank the Center, College, and President for their support as well. We also wish to thank the editorial board of InVisible Culture for publishing this issue in a curated model distinct from their typical peer-review process for an issue. Clara Auclair and Byron Fong put in countless hours editing the interview, for which Kendall DeBoer and Peter Murphy worked on the citations. This same group worked on image permissions and graphic layout for "Black Futurities." Four managing editors (Jerome Dent, Patrick Sullivan, Alisa V. Prince, and Julia Tulke) shepherded this issue to publication since it was conceived, and Daly Arnett, Jacob Carter, Tierney Hamilton, and Christian Sancto assisted with copyediting and uploading for publication. Thanks as well to Ouma Amadou, who also assisted with image permissions. We appreciate the patience and persistence of everyone involved. This essay is dedicated to the future of Black Studies at UR-and to Black futurities everywhere. 


\section{Special Thanks}

The managing editor of IVC and the editors of this special issue are particularly grateful to Quajay Donnell, Martin Hawk, and Erica Jae, three local photographers whose documentation of racial justice activism in Rochester and Washington DC through the summer and fall of 2020 visually grounds this issue. Their contributions appear in this introduction as well as the featured images of articles in the sections Black Studies Now and In the Imperial Archives with Hazel Carby.

\section{Footnotes}

1. Hazel V. Carby, "Black Futurities: Shape-Shifting beyond the Limits of the Human," InVisible Culture 31 (2020) https://www.invisibleculturejournal.com/pub/black-futurities $\triangleq$

2. The editors recognize that there is a shift occurring around placing "Black/black" in upper or lower case right now, a shift aligned with the racial reckoning nationally and globally at present. We did not impose a policy as to one or the other, allowing authors to decide for themselves. In the introduction, we chose to capitalize "Black" when we wrote it and leave it as it was in a quotation from a contributor or source. But throughout the issue, we decided that allowing for the upper-lower case variation effectively registers the transformation of the racial order through which we may be living. A similar logic was applied to "Indigenous/indigenous," but we actively decided not to capitalize "white."

3. Coverage of Daniel Prude's death has been extensive in multiple outlets ranging from the New York Times to The Guardian. We initially drew on this article: "Daniel Prude: New York police used 'spit hood' on Black man who died of asphyxiation," The Guardian, September 3, 2020, https://www.theguardian.com/usnews/2020/sep/02/new-york-police-spit-hood-black-man-died-asphyxiation. Video of the encounter between Prude and the Rochester Police Department-which, viewers should know before watching, is very disturbing — can be found at "Daniel Prude death: Rochester police body cam footage (10-min. version)," Democrat \& Chronicle, September 4, 2020, https://www.democratandchronicle.com/videos/news/2020/09/04/daniel-prude-deathrochester-police-body-cam-video-10-minute-version/5710351002/. The problems of 
circulating images such as this one are not simple or easy. For a classic essay on this topic, see Elizabeth Alexander, "'Can you be BLACK and Look at This?': Reading the Rodney King Video(s)," Public Culture 7, no. 1 (1994): 77-94. Hazel Carby has more recently described and discussed the video of George Floyd's death in "Peine forte et dure," London Review of Books, July 20, 2020, https://www.lrb.co.uk/thepaper/v42/n15/hazel-v.-carby/peine-forte-et-dure. Alanna and Alisa Prince take up the circulation of images of white supremacist violence in their essay for this issue of InVisible Culture too. $\_$

4. "My education is and isn't a product of the 'disorderly year' of 1968," writes Carby, "a year fissured by contradictions that have long since been paved under a seamless cultural mythology of student rebellion." See Hazel V. Carby, "Lost (and Found?) in Translation," Small Axe 13, no. 1 (2009): 31. For more on the cultural mythology of 1968, see Kristin Ross, May '68 and Its Afterlives (Chicago: University of Chicago Press, 2002) and Jonathan Flatley and Robert Bird, eds., "1968 Decentered," special issue of South Atlantic Quarterly 119, no. 3 (2020).. 5. Hazel V. Carby, Imperial Intimacies: A Tale of Two Islands (New York: Verso, 2019).

6. Stefano Harney and Fred Moten, The Undercommons: Fugitive Planning and Black Study (New York: Minor Compositions, 2013), 109. $\_$

7. Imperial Intimacies is concerned with this violently financial history, especially when Carby explores imperial accounting and colonial bookkeeping. Also see Ian Baucom, Specters of the Atlantic: Finance Capital, Slavery, and the Philosophy of History (Durham: Duke University Press, 2005); and Kara Keeling, Queer Times, Black Futures (New York: New York University Press, 2019). $\_$

8. This is a problem Carby herself has addressed in her tellingly entitled essay "The New Auction Block: Blackness and the Marketplace," in A Companion to AfricanAmerican Studies, ed. Lewis R. Gordon and Jane Anna Gordon (Malden: Blackwell Publishing, 2006), 119-135. Carby argues that African American Studies underwent a dangerously myopic commodification by the media in the 1990s-a market moment paternalistically fixated on a few Black male scholars, especially Henry Louis Gates, Jr. and Cornel West-at the cost of the "potential for imagining any profound transformation in the racial and ethnic order" as it exists within "an unrepentantly capitalist world order." As she states in "The New Auction Block," "Perhaps this is why the media are most comfortable with black intellectuals who function as an 
extension of black entertainment, as professionally racialized bodies reduced to perform spectacular acts of blackness in intellectual face" (135). For a related view, see the chapter entitled "Publicity: Black Intellectuals as Inorganic Representatives" in John Michael, Anxious Intellects: Academic Professionals, Public Intellectuals, and Enlightenment Values (Durham: Duke University Press, 2000), 23-43.

9. In our interview with her, Carby recalled Antonio Gramsci's stance that we must conjoin pessimism of the intellect with optimism of the will. Gramsci had significant influence on the cultural studies formation out of which Carby emerged, as in Stuart Hall's important 1986 essay "Gramsci's Relevance for the Study of Race and Ethnicity," in Stuart Hall: Essential Essays, Volume 2: Identity and Diaspora, ed. David Morley (Durham: Duke University Press, 2019), 21-54. $\subseteq$ 10. Carby, "Lost (and Found?)," 40.

11. Gilroy, Sharpe, and King turn to these similarly oceanic and geologic sand-lea figures respectively in The Black Atlantic: Modernity and Double Consciousness (Cambridge: Harvard University Press, 1993), In the Wake: On Blackness and Being (Durham: Duke University Press, 2016), and The Black Shoals: Offshore Formations of Black and Native Studies (Durham: Duke University Press, 2019). We tutored ourselves in the ways currents work by turning to "Currents," National Oceanic and Atmospheric Administration, accessed October 2, 2020, https://oceanservice.noaa.gov/education/tutorial currents/welcome.html. $\triangleq$ 12. In structuring this essay around four countercurrents, we take a certain amount of inspiration from Ramzi Fawaz, "'An Open Mesh of Possibilities': The Necessity of Eve Sedgwick in Dark Times," in Reading Sedgwick, ed. Lauren Berlant (Durham: Duke University Press, 2019), 6-33.

13. Carby, "New Auction Block," 122.

14. We borrow "living thought" from the effort to rethink Theodor Adorno that Miriam Hansen attempts in "Mass Culture as Hieroglyphic Writing: Adorno, Derrida, Kracauer," New German Critique 56 (1992): 44.

15. Dennis Dworkin, Cultural Marxism in Postwar Britain: History, the New Left, and the Origins of Cultural Studies (Durham: Duke University Press, 1997), 181. Also see Houston A. Baker, Jr., Manthia Diawara, and Ruth H. Lindeborg, eds., Black British Cultural Studies: A Reader (Chicago: The University of Chicago Press, 1996). In their helpful introduction, Baker, Lindeborg, and Stephen Best use language that overlaps 
with the figure of countercurrents we adopt here. "Black British cultural studies," they write, "has as many intellectual currents and eddies as it has practitioners, and sometimes the project seems to be as much 'history' as it is 'autobiography,'” a hypothesis that Carby's Imperial Intimacies validates in its own "auto-historical" project. Carby describes the book as auto-history in Kathleen McGarvey,

“Distinguished Visiting Humanist Hazel Carby dissects race and empire," University of Rochester Newscenter, January 23, 2019, https://www.rochester.edu/newscenter/distinguished-visiting-humanist-hazel-carby_ dissects-race-and-empire-358972/.

16. Stuart Hall, “Cultural Studies: Two Paradigms,” Media, Culture and Society 2, no. 1 (1980): $57 . \unlhd$

17. Dworkin, Cultural Marxism in Postwar Britain, 181. See Centre for Contemporary Cultural Studies, The Empire Strikes Back: Race and Racism in 70 s Britain (London: Hutchinson, 1982). $匚$ 18. Hazel V. Carby, Reconstructing Womanhood: The Emergence of the AfroAmerican Woman Novelist (New York: Oxford University Press, 1987), and Hortense J. Spillers, “Mama's Baby, Papa’s Maybe: An American Grammar Book,” Diacritics 17, no. 2 (1987): 64-81. Earlier work relevant to what Carby and Spillers are attempting in these includes, for instance, Angela Y. Davis, Women, Race and Class (New York: Vintage Books, 1981); recent relevant work includes, for instance, Denise Ferreira da Silva, "Hacking the Subject: Black Feminism and Refusal beyond the Limits of Critique," philoSOPHIA 8, no. 1 (2018): 19-41; and Imani Perry, Vexy Thing: On Gender and Liberation (Durham: Duke University Press, 2018).

19. Carby, Reconstructing Womanhood, 4.$\lrcorner$

20. Carby, Reconstructing Womanhood, 166, 168, 174.

21. Carby, Reconstructing Womanhood, 164.

22. Saidiya Hartman and Tina Campt, "A Future beyond Empire: An Introduction," Small Axe 13, no. 1 (2009): 20. This essay introduces a cluster that commemorates Reconstructing Womanhood on its twenty-fifth anniversary, and includes writing by Carby, Anne McClintock, Rinaldo Walcott, Lisa Lowe, and Robert Reid-Pharr. 23. See the first chapter of Carby, Reconstructing Womanhood, "'Women's Era: Rethinking Black Feminist Theory," 3-19. 
24. Hazel V. Carby, Race Men (Cambridge: Harvard University Press, 1998). 25. Carby, Reconstructing Womanhood, 17-19. In footnotes 34 and 35 to the first chapter of Reconstructing Womanhood, Carby cites multiple Stuart Hall essays. Most important to the model of articulated hierarchy is his foundational text of 1980, "Race, Articulation, and Societies Structured in Dominance," in Stuart Hall: Essential Essays, Volume 1: Foundations of Cultural Studies, ed. David Morley (Durham: Duke University Press, 2019).

26. Carby, Reconstructing Womanhood, 17, 15. The famous first paragraph to Spillers's essay includes the following sentences with phrasing akin to Carby's: "I describe a locus of confounded identities, a meeting ground of investments and privations in the national treasury of rhetorical wealth. My country needs me, and if I were not here, I would have to be invented." Spillers, "Mama’s Baby," 65. 27. Kimberlé Williams Crenshaw, "Demarginalizing the Intersection of Race and Sex: A Black Feminist Critique of Antidiscrimination Doctrine, Feminist Theory and Antiracist Politics," University of Chicago Legal Forum 19891 (1989): 139-167. For a recent engagement with the intersectional countercurrent, see Jennifer C. Nash, Black Feminism Reimagined: After Intersectionality (Durham: Duke University Press, 2018).

28. Frank B. Wilderson III, Red, White, and Black: Cinema and the Structure of US Antagonisms (Durham: Duke University Press, 2010), 18. The "paradigmatic analysis" (7), as Wilderson terms it in his introduction, is central to his stunning project in this book; it is the source of our characterization of the ontological position as often a paradigmatic one. Sharon Patricia Holland, Raising the Dead: Readings of Death and (Black) Subjectivity (Durham: Duke University Press, 2000), 5, 7. 29. Chris Chen, "The Limit Point of Capitalist Equality: Notes towards an Abolitionist Antiracism," Endnotes 3 (2013), https://endnotes.org.uk/issues/3/en/chrischen-the-limit-point-of-capitalist-equality. Also see Frank Wilderson III, “Gramsci's Black Marx: Whither the Slave in Civil Society?" Social Identities 9, no. 2 (2003): 225240. Salient here is Saidiya V. Hartman, Scenes of Subjection: Terror, Slavery, and Self-Making in Nineteenth-Century America (New York: Oxford University Press, 1997). $\subseteq$

30. Darby English, To Describe a Life: Notes from the Intersection of Art and Race Terror (New Haven: Yale University Press, 2019), 21.

31. Carby, Reconstructing Womanhood, 17. 
32. Hazel V. Carby, "Policing the Black Woman's Body in an Urban Context," in Cultures in Babylon: Black Britain and African America (New York: Verso, 1999), 36. $\underline{-}$

33. Hazel V. Carby, "The Sexual Politics of Blues," in Cultures in Babylon: Black Britain and African America (New York: Verso, 1999), 7-21.

34. Hazel V. Carby, "White Woman Listen! Black Feminism and the Boundaries of Sisterhood," in Cultures in Babylon: Black Britain and African America (New York: Verso, 1999), 67-92.

35. Carby, "White Woman Listen," 67. As a signifier in the British political and cultural context of the late twentieth century, "black" could refer to people of African, Caribbean, and Asian origin or descent. Kwame Anthony Appiah has recently reminded us of this countercurrent in Black British thought in "What We Can Learn from the Rise and Fall of 'Political Blackness,'” New York Times, October 7, 2020, https://www.nytimes.com/2020/10/07/opinion/political-blackness-race.html. Also see the introduction to Kobena Mercer's Welcome to the Jungle: New Positions in Black Cultural Studies (New York: Routledge, 1994), 1-32; and Stuart Hall, "New Ethnicities," in Black British Cultural Studies: A Reader, ed. Houston A. Baker, Jr., Manthia Diawara, and Ruth H. Lindeborg (Chicago: The University of Chicago Press, 1996), 163-172. Carby takes up the complexity of Blackness in a British context in Imperial Intimacies, though we would also refer interested readers to her fascinating essay, the title of which riffs on a famous relevant Hall essay, "What is this 'Black' in Irish Popular Culture?” European Journal of Cultural Studies 4, no. 3 (2001): 325-349. $\Xi$

36. Carby, "White Woman Listen," 88. For a powerfully and alternatively humanist discussion of the post-imperial British state in relation to race and ethnicity, see Paul Gilroy, Postcolonial Melancholia (New York: Columbia University Press, 2005). $\_$ 37. Carby, "White Woman Listen," 88, emphases ours. $\_$ 38. Toni Morrison, "What the Black Woman Thinks About Women's Lib," New York Times, August 22, 1971, https://www.nytimes.com/1971/08/22/archives/what-theblack-woman-thinks-about-womens-lib-the-black-woman-and.html.. 39. Audre Lorde, "The Transformation of Silence into Language and Action," in Sister Outsider: Essays and Speeches (Berkeley: Crossing Press, 2015), 40-44. 
40. Carby uses the phrase "system of alliances" to describe solidarity in "America Inc.-The Crisis at Yale: A Tale of Two Women," in Cultures in Babylon: Black Britain and African America (New York: Verso, 1999), 117.

41. Carby, "White Woman Listen," 89.

42. The quotation is taken from Michelle Ann Stephens, "Getting Next to Ourselves: The Interpersonal Dimensions of Double-Consciousness," Contemporary Psychoanalysis 54, nos. 2-3 (2020): 214. Stephens examines campus incidents around race and racism dominated rhetorically by the genres of accusation and confession in order to consider both "white guilt" and "black rage." She draws on W.E.B. Du Bois, Frantz Fanon, and Jean-Paul Sartre to speculate on ways of navigating interracial conflict through modes of intersubjectivity that could, as we suggest above, have both political and psychic implications for building solidarity. The multiracial coalition has come under significant critique as anti-Black in the past decade, as in Jared Sexton, Amalgamation Schemes: Antiblackness and the Critique of Multiracialism (Minneapolis: University of Minnesota Press, 2008). This critique needs to be seen in terms of the rise of Black Lives Matter too, of which the following are only two of many rich points of departure: Keeanga-Yamahtta Taylor, From \#BlackLivesMatter to Black Liberation (Chicago: Haymarket Books, 2016) and Jared Sexton, Black Men, Black Feminism: Lucifer's Nocture (London: Palgrave Macmillan, 2018), especially the chapter entitled "Unbearable Blackness." 43. Brian Sharp, "Police Investigating Possible Hate Crime on Rochester's East Side," Democrat \& Chronicle, August 1, 2020, https://www.democratandchronicle.com/story/news/2020/08/01/police-investigatingpossible-hate-crime-rochesters-east-side/5564273002/. $\Perp$

44. Hazel V. Carby, "Safe? at Home?" from the special blog collection on "Confronting 'the Household," Feminist Review, July 6, 2020, https://femrev.wordpress.com/2020/07/06/safe-at-home/. 45. For more information on the Scholar Strike across the US and at UR, respectively see the following websites: https://www.scholarstrike.com/ and http://www.sas.rochester.edu/gsw/news-events/events/2020-09-08_strike.html. $\triangleq$ 46. See, for instance, Hazel V. Carby, "Race and the Academy: Feminism and the Politics of Difference," and "America Inc. - The Crisis at Yale: A Tale of Two Women," 
in Cultures in Babylon: Black Britain and African America (New York: Verso, 1999), 93-99, 116-126.

47. Bess Connolly, "Yale's Hazel Carby retires, leaving legacy of mentorship and scholarship," YaleNews, June 17, 2019, https://news.yale.edu/2019/06/17/yales-hazelcarby-retires-leaving-legacy-mentorship-and-scholarship\#.. 48. See "About Us," Yale University Department of African American Studies, accessed October 19, 2020, https://afamstudies.yale.edu/about-us. 49. See "Graduate Program," Yale University Department of African American Studies, accessed October 19, 2020, https://afamstudies.yale.edu/academics/graduate-program. 50. Carby, “Lost (and Found)," 35. 51. Hazel V. Carby, "The Multicultural Wars, Part One," in Cultures in Babylon: Black Britain and African America (New York: Verso, 1999), 249. 52. Carby, "The Multicultural Wars, Part One," 247-248, 245.

53. Carby, "America Inc.," 117. $\_$

54. Carby, "The Multicultural Wars, Part One," 249-50.

55. Department of Physics \& Astronomy, University of Rochester, "On the Underrepresentation of African Americans in the Department of Physics \& Astronomy at the University of Rochester... and What We'll Do About It," last updated July 11, 2020, accessed October 13, 2020, https://docs.google.com/document/d/1x6WnX3nqyCbOptDR2HNNmUwsy70ilk4uxqeG

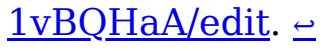

56. Hazel V. Carby, "The Multicultural Wars, Part Two," in Cultures in Babylon: Black Britain and African America (New York: Verso, 1999), 257. 57. Bruce Popper, “The University of Rochester's Role in Racially Based Poverty in Our City: An open letter to UR President Sarah Mangelsdorf and UR Medicine CEO Dr. Mark Taubman," June 10, 2020.

58. Molly Ball, email message to Joel Burges, October 8, 2020. Thanks as well to Kathryn A. Mariner for "Fallow Time: Race and Placemaking in Rochester, NY," 
lecture delivered to the Anthropology Colloquium, New York University, October 1, 2020.

59. Hazel V. Carby, "Figuring the Future in Los(t) Angeles," in Now Dig This! Art and Black Los Angeles, 1960-1980, ed. Kellie Jones (Los Angeles: Hammer Museum and New York: Delmonico Books-Prestel, 2011), 98.

60. Carby, Imperial Intimacies, $3 . \ominus$

61. Hazel V. Carby and Heather V. Vermeulen, Prospects of Empire: Slavery and Ecology in Eighteenth-Century Atlantic Britain, catalogue essay for an exhibition at the Lewis Walpole Library, Yale University (New Haven: Office of the Yale University Printer, 2014, 2015), 10.

62. Cheryl A. Wall, "Introduction: Taking Positions and Changing Words," in Changing our Own Words: Essays on Criticism, Theory, and Writing by Black Women, ed. Cheryl A. Wall (New Brunswick: Rutgers University Press, 1989), 6. 63. Carby's prose has taken a significant turn since "Lost (and Found?) in Translation," the last paragraph of which is a remarkable instance of that turn. The prosaic, we would argue, is an important stylistic category for understanding how Hazel Carby writes and how that writing mediates her politics. $\bullet$ 64. Kathryn A. Mariner, Contingent Kinship: The Flows and Futures of Adoption in the United States (Berkeley: University of California Press, 2019), 27. 65. Kara Keeling, Queer Times, Black Futures (New York: New York University Press, 2019), ix. $\subseteq$

66. Keeling, Queer Times, xi. $\subseteq$

67. Carby, "Peine forte et dure." $\triangleq$

68. Imani Perry, Breathe: A Letter to My Sons (Boston: Beacon Press, 2019). 69. For more information, see "Coronavirus (COVID-19)," Centers for Disease Control and Prevention, accessed October 19, 2020, https://www.cdc.gov/coronavirus/2019-nCoV/index.html. $\doteq$

70. Dionne Brand, "On narrative, dying and the calculus of living and dying," Toronto Star, July 4, 2020, https://www.thestar.com/entertainment/books/2020/07/04/dionne-brand-on-narrative- 
reckoning-and-the-calculus-of-living-and-dying.html. Ibram X. Kendi made a related point on Twitter this year: "Any return to normal is a return to the normality of racism" (@DrIbram, June 26, 2020).

71. Jaqueline Bobo, Cynthia Hudley, and Claudine Michel, "Introduction," in The Black Studies Reader, ed. Jaqueline Bobo, Cynthia Hudley, and Claudine Michel (New York: Routledge, 2004), 2. $匚$ 